\title{
Prediction Model of Elastic Modulus for Granular Road Bases
}

\author{
Zainab Ahmed Alkaissi ${ }^{1} \&$ Hassan Adnan ${ }^{1}$ \\ ${ }^{1}$ Highway and Transportation Department, College of Engineering, Mustansiriyah University, Baghdad, Iraq \\ Correspondence: Zainab Ahmed Alkaissi, Highway and Transportation Department, College of Engineering, \\ Mustansiriyah University, Baghdad, \\ dr.zainabalkaissi77@uomustansiriyah.edu.iq/zainabalkaisi77@googlemail.com
}

Received: March 11, 2020 Accepted: March 19, 2020 Online Published: April 2, 2020

\begin{abstract}
The estimation of elastic modulus for road bases is the primary objective of this research which is implemented a significant role in transmitting the vertical loading to the pavement foundation layers. In this study, the effect of weathering conditions on the stiffness of base course is investigated and implied the durability test by subjecting the prepared samples to a different numbers of wet-dry cycles $(0,2,4,6,8$ and 10). A conventional base materials of local natural gravel aggregate and treated base materials with recycled concrete aggregate RCA at different percentages $(0 \%, 25 \%, 50 \% 75 \%$ and $100 \%)$ is adopted in this research.

The elastic characteristics are estimated in terms of elastic modulus. Elastic modulus are estimated by passing the ultrasonic pulse velocity through the untreated and treated base materials laboratory specimens. This test can be used to study the elastic modulus properties of base materials. A multiple linear regression analysis is used for prediction the elastic modulus using the SPSS (software ver.21). Elastic Modulus (kPa) is the dependent variable whereas the independent variable are; No. of wet- dry cycle and Percent (\%) of RCA stabilizer. The obtained results for elastic modulus (Es) of granular base material layer showed increasing in elastic modulus with percentage of RCA\%., results revealed that the (Es) values reached a maximum value of $(6927 \mathrm{kPa})$ for $100 \%$.

For the OMC's values increases due to the percentage increment of RCA in granular base material mixture, this increment in water contents is refer to high absorption capacity of the paste clinging to the RCA. On other side the dry density decrease gradually with adding percentage of (RCA) in granular base material mixture.
\end{abstract}

Keywords: elastic modulus, predictive model, RCA, Wet-Dry Cycles, road bases

\section{Introduction}

The behaviour and performance of pavements against distresses rutting has significantly influence by the design standard (including the estimation of resilient elastic modulus) and construction of the granular base layer. Achieving the long-life of pavements is depending on the control of granular base layer construction quality (Titi, et.al 2018). Also the growth in axle loads and number of vehicles in industrial and developing countries has make road agencies to modify their design standards and to adopt designs that provide roads with higher load bearing capacity. Also Titi, and Matar (2018) predicted a model of the resilient modulus of base granular layer using repeated triaxial test using gravel /crushed grave and crushed stone (Titi and Matar, 2018).

The elastic modulus of granular pavement layers is considered as the most important parameters in pavement design procedures. Optimum pavement design requires to determine the appropriate stiffness value for each pavement layer.

Stabilize and improve the engineering behaviour of granular pavement layers is considered as important in the desired engineering properties of compacted granular layers construction, not only its moisture content and dry density. Various studies have been achieved over the years with respect to engineering properties of granular base materials and the effect of (wet-dry cycles) on such properties. These preceding studies concentrated on mechanical strength properties and how such these properties are affected by weathering impact (Biswal, et.al. 2018).

\section{Experimental Work}

The experimental work of this study includes the laboratory tests for (30) samples of granular base material prepared from locally Al-Nibaee aggregate material treated with crushed concrete waste material; recycled 
concrete aggregate (RCA). Also the durability test for several wet-dry cycles; 0, 2, 4, 6,8, 10 and 12 were carried out.

\subsection{Materials}

The materials used are locally available in Iraq taken from the hot mix plant of Al-Nibaee quarry at Al-Taji used in road paving works. The aggregate used is crushed aggregate and Recycled concrete aggregate (RCA) from stocks of construction waste materials.

\subsubsection{Aggregate}

The Unified Soil Classification System (USCS) (ASTM Standard D2487), soil can be divided into coarse and fine aggregate, as follows:

\subsubsection{Coarse Aggregate}

Crushed aggregate is used while all rounded aggregates are removed. The physical properties and chemical composition of the coarse aggregate are shown in Tables (1) and (2) respectively.

Table 1. Physical Properties of Nibaee Aggregate

\begin{tabular}{lcc}
\hline Property & Coarse Aggregate & Fine Aggregate \\
\hline Bulk Specific Gravity (ASTM C127 and C128). & 2.681 & 2.6303 \\
Apparent Specific Gravity (ASTM C127 and C128). & 2.602 & 2.46 \\
Percent Water Absorption (ASTM C127 and C128). & 0.45 & 0.53
\end{tabular}

*The test was done in cooperation with National Center for Construction Laboratories and Researches (Baghdad).

Table 2. Chemical Composition of Nibaee Aggregates.

\begin{tabular}{ll}
\hline Chemical Compound & \% Content \\
\hline Silica,SiO2 & 82.52 \\
Lime, $\mathrm{CaO}$ & 5.37 \\
Magnesia, $\mathrm{MgO}$ & 0.78 \\
Sulfuric Anhydride, SO3 & 2.71 \\
Alumina, Al2O3 & 0.48 \\
Ferric Oxide, Fe2O3 & 0.69 \\
Loss on Ignition & 6.55 \\
TSS(total soluble salts)\% & 1.9 \\
Organic matter (\%) & 0.5 \\
Gypsum content (\%) & 0.45 \\
Mineral Composition & \\
Quartz & 80.3 \\
Calcite & 10.92
\end{tabular}

*The test was done in cooperation with National Center for Construction Laboratories and Researches (Baghdad).

\subsubsection{Fine Aggregate}

The fine aggregate refers to a combination of natural sand (river sand). The physical composition and chemical properties of the fine aggregate are shown in Tables (1) and (2) respectively.

The State Corporation for Roads \& Bridges in Iraq (SCRB, 2003) established standard specifications for base course. The gradation used in this research is shown in Table (3) and Figure (1). 


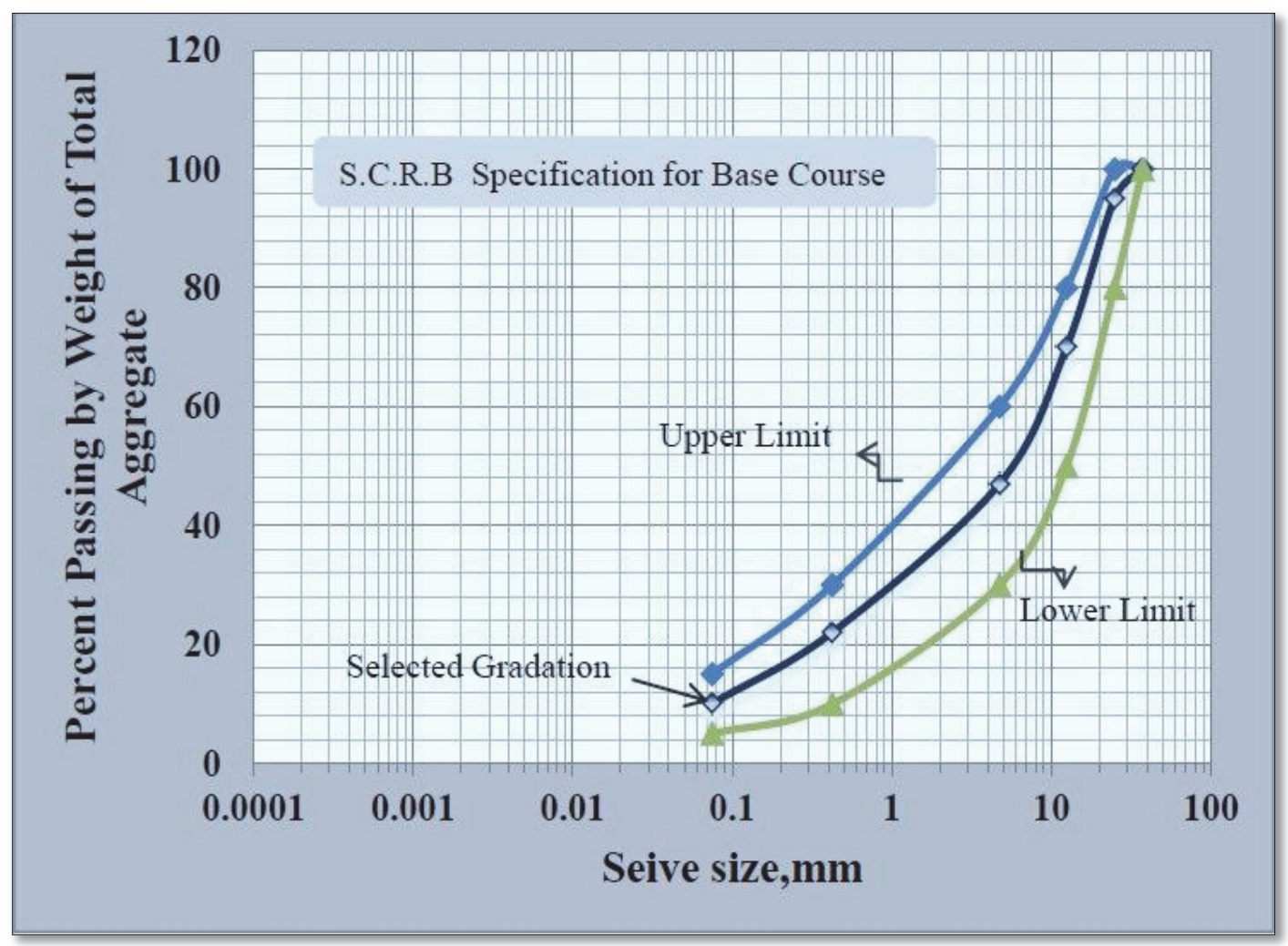

Figure 1. Specification Limits and Gradation for Base Course (SCRB, 2003)

Table 3. Gradation of the Aggregate for Base Course (SCRB, 2003)

\begin{tabular}{clcc}
\hline \multicolumn{2}{l}{ Sieve Size } & $\begin{array}{l}\text { Sieve } \\
\text { Opening } \\
(\mathrm{mm})\end{array}$ & \multicolumn{2}{c}{ Percentage Passing by Weight of total Aggregate } \\
\cline { 3 - 4 } & & $\begin{array}{l}\text { Base Course } \\
\text { Specification Limit } \\
\text { (SCRB, 2003) }\end{array}$ & $\begin{array}{c}\text { Specification Limit } \\
\text { (SCRB,2003) }\end{array}$ \\
$1^{1 / 2 "}$ & 37.5 & 100 & 100 \\
$1^{\prime \prime}$ & 25.0 & $80-100$ & 95 \\
$1 / 2^{\prime \prime}$ & 12.5 & $50-80$ & 70 \\
No.4 & 4.75 & $30-60$ & 47 \\
No.40 & 0.425 & $10-30$ & 22 \\
No.200 & 0.075 & $5-15$ & 10 \\
\hline
\end{tabular}

\subsubsection{Mineral Filler}

In this study the mineral filler used fine aggregate (passing sieve NO.200). Mineral filler is thoroughly dry and free from lumps or aggregations of fine particles.

\subsubsection{Recycled Concrete Aggregate (RCA)}

The use of reclaimed concrete aggregate promised to be a technically-viable solution that offers economic and environmental advantages. Reclaimed concrete aggregate, collected from waste materials, results from the waste concrete blocks of laboratory in the College of Engineering Al-Mustansiriyah University. Plate (1) shows reclaimed concrete aggregate materials. The gradation used in this study according to SCRB specification for base course (SCRB, 2003), as shown in Table (3) and Figure (1). 


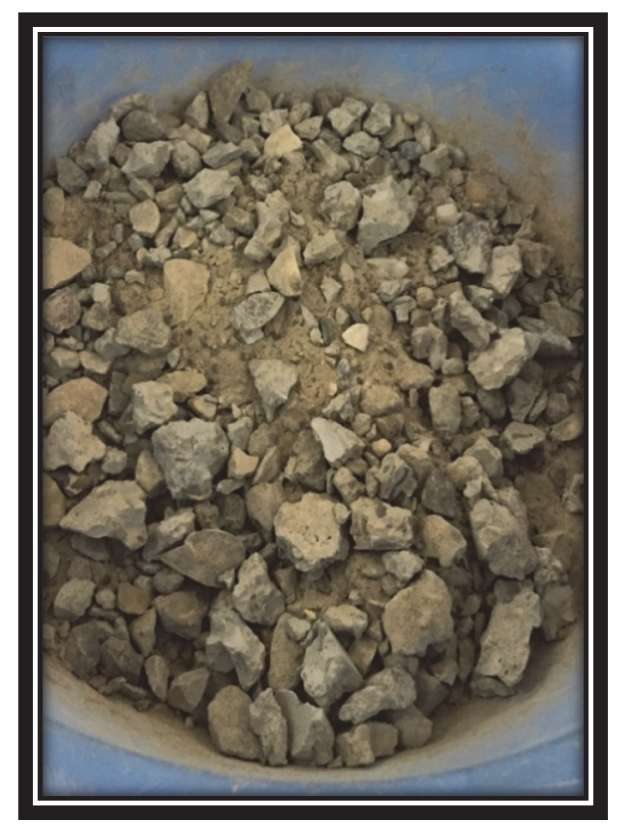

Plate 1. Reclaimed Concrete Aggregate Materials (RCA).

RCA tends to be very angular and rough due to the crushing of the virgin aggregate particles and the presence of cement paste that continues to cling to the surfaces of the aggregate. It has higher absorption capacity of water than natural aggregate due to the porous nature of the cement paste portion of the recycled aggregates so at equal water to cement ratio RCA concrete gave lower compressive strength than control concrete made from natural aggregate as well as it has lower elastic modulus than control and similar flexural strength (Alkaissi, et.al, 2016). The Specific Gravity of RCA is lower than natural aggregate due to the crushed mortar present in and on the aggregate particles which make it less dense (low dry density) than NA because of its porosity and entrained air voids. The loss for RCA in L.A. Abrasion Mass Loss is usually higher than NA (Alkaissi, et.al, 2016). In terms of durability properties, RCA concrete has high chloride contents (Sharma and Singla, 2014) that may effect on the durability of the new concrete and the corrosion of steel in new concrete. Table (4) shows a comparison Between NA \& RCA Properties:

Table 4. Physical Properties of NA \& RCA (Sharma and Singla, 2014)

\begin{tabular}{lcc}
\hline Property & NA & RCA \\
\hline Shape and Texture & $\begin{array}{c}\text { Well rounded, smooth } \\
\text { to angular and rough }\end{array}$ & $\begin{array}{c}\text { Angular with rough } \\
\text { surface }\end{array}$ \\
Absorption Capacity & $0.8-3.7 \%$ & $3.7-8.7 \%$ \\
Specific Gravity & $2.4-2.9$ & $2.1-2.4$ \\
L.A. Abrasion & $15-30 \%$ & $20-45 \%$ \\
Test Mass Loss & & \\
Chloride Content & $0-1.2 \mathrm{~kg} / \mathrm{m} 3$ & $0.6-7.1 \mathrm{~kg} / \mathrm{m} 3$ \\
\hline
\end{tabular}

\subsubsection{Additives (Cement)}

Portland cement is used as stabilizer. The chemical composition and physical properties of Portland cement are shown in Table (5). 
Table 5. Chemical Composition \& Physical Properties of Cement Types used

\begin{tabular}{ll}
\hline Chemical Compound & \% Content \\
\hline Silica, Sio2 & 21.54 \\
Lime, $\mathrm{CaO}$ & 62.2 \\
$\mathrm{SiO3}$ & $\ldots \ldots \ldots$ \\
Sulfuric Anhydride, $\mathrm{SO} 3$ & 1.5 \\
Alumina, $\mathrm{Al2O} 3$ & 4.4 \\
Magnesia $(\mathrm{MgO})$ & 3.7 \\
Ferric Oxide, $\mathrm{Fe} 2 \mathrm{O} 3$ & 5.3 \\
$\mathrm{~K}_{2} \mathrm{O}$ & \\
$\mathrm{Na}_{2} \mathrm{O}$ & 0.58 \\
Loss on Ignition (L.O.I) & 0.3 \\
I.R & 0.48 \\
$\mathrm{Ca}(\mathrm{OH})_{2}$ & $\ldots \ldots \ldots$ \\
Total & 100 \\
Physical properties & \\
\%Passing Sieve No. 200 & 98 \\
Apparent Specific Gravity & 3.4 \\
\hline
\end{tabular}

*The test was done in cooperation with National Center for Construction Laboratories and Researches (Baghdad).

\subsection{Sample Preparation}

1) Determination of relative proportions of cement and the aggregate as well as percent of each aggregate size fractions involving filler.

2) Separated over the 1", 1/2", No. 4, No. 40, and No. 200 sieves.

3) After the bulk samples are sieved, a particle-size distribution is established for each material that facilitated reconstruction of replicate samples with identical gradations.

\section{- Preparation of Aggregate}

The aggregates and filler for conventional materials and non-conventional materials (recycled concrete aggregate (RCA)) are prepared using the same procedure. The weight of each aggregate size and filler is determined by multiplying its percent by the desired weight of final mix. The use of RCA is about $(25,50,75$ and 100) percentage replaced from coarse aggregate.

\section{- The Process of Mixing}

The total weight of the batch was approximately $5500 \mathrm{gm}$ to produce a testing sample. (9) samples with different moisture contents are prepared for moisture-density testing of untreated materials aggregate treated with (RCA) materials. Just before compaction, the dry fine fraction, passing the No. 4 sieve and mineral filler, was added to the coarse fraction to get more appropriate mix. The combined material is then mixed until it becomes uniform in color and texture. In case of treated material with cement, the cement is added to the fine fraction and then mixed until it reaching uniform mix; finally it mixed with the coarse fraction. The final mixture has been compacted into the mold using modified Proctor compaction effort using a mechanical compactor in accordance with (ASTM D698 - 12). The test machines are shown in plate (2). 


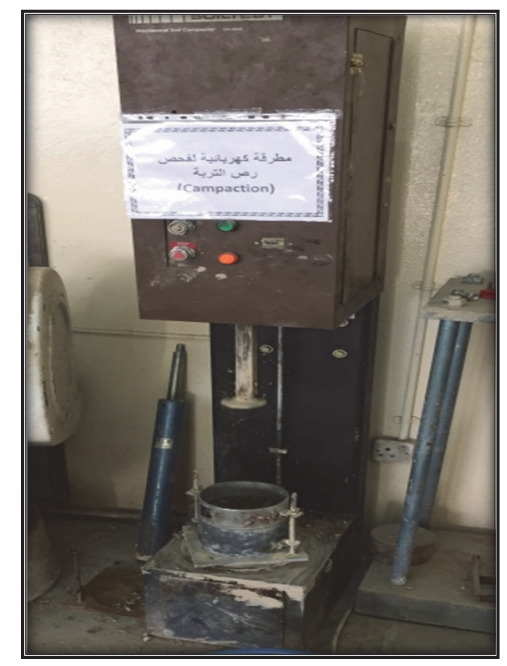

Plate 2. Modified Proctor Compaction Test

The modified Proctor procedure requires compaction of the samples in five layers; each lift consists of 56 blows. The specimen is subsequently dried to constant weight in an oven at $(105-110){ }^{\circ} \mathrm{C}$ for 24 hours to facilitate calculation of gravimetric moisture content and dry density. The moisture content determinations are performed in accordance with (ASTM D 2216 - 05). These values were plotted to determine the optimum moisture content (OMC) and maximum dry density (MDD), see Plate (3).

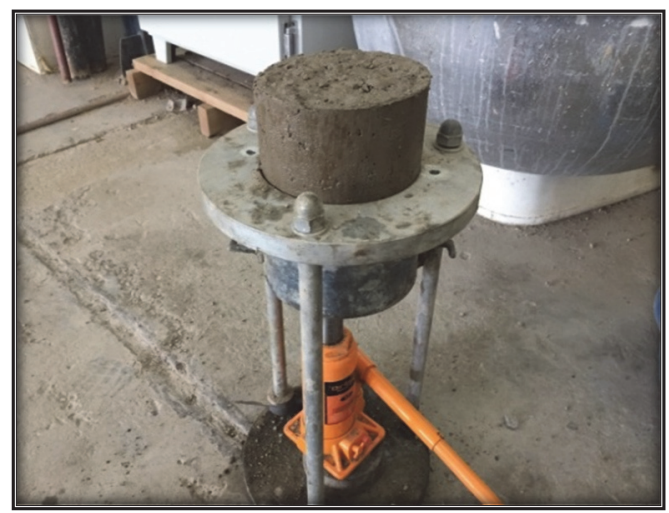

Plate 3. Extruded Sample.

\section{Wet-Dry Test}

Wet-dry cycle test, is one of durability tests that adopted in this study used to investigate the weathering conditions effects on the stiffness of the base course with selected percentage value of $(0 \%, 25 \%, 50 \%, 75 \%$ and $100 \%)$ RCA.

Six Samples of aggregate material are prepared for 12 cycles. These samples are compacted as described above at OMCs for each ratio and for each compaction method, extruded from mould and cured at moist room for 7 days. After the 7 days cure, all samples are submerged in potable water at room temperature for a period of ( 5 hours). Following the period of immersion, samples are removed from water and the mass of each sample is weighted and recorded. Then, each sample is placed in an oven at $71^{\circ} \mathrm{C}\left(160^{\circ} \mathrm{F}\right)$ for $(42$ hours $)$ and removed; the mass is then weighed and recorded. This process of wetting and drying constitutes one cycle (48 hour). Plate (4) depicts the wetting and drying configurations for samples of treated Al-Nibaee aggregate materials for wet-dry test, as prescribed in ASTM D 559-96. 


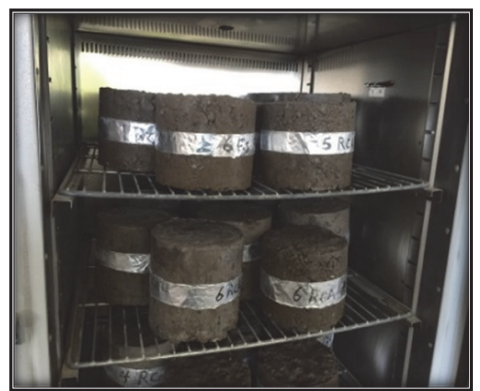

a) Sample in oven

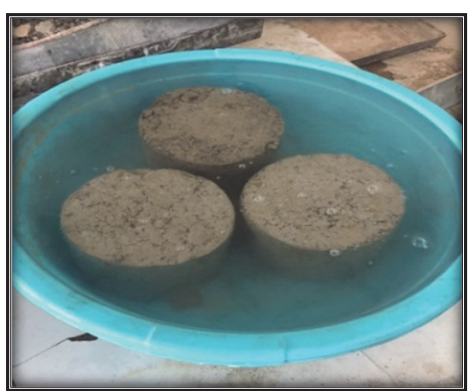

b) Submerged sample

Plate 4. Samples Submerged in Potable Water

\section{Ultrasonic Test}

Ultrasonic test is a non destructive testing which has been utilized for characterization of granular base materials. It is used to measure the travel time of an ultrasonic pulse wave passing through the prepared specimens. The elastic characteristics are estimated in terms of elastic modulus. Elastic modulus are estimated by passing the ultrasonic pulse velocity through the untreated and treated base materials. This test can be used to study the stiffness of elastic modulus properties of base materials. The test is used to find the elastic modulus from the recording transit time $A S T M$ (C 597 - 02).

\section{Results and Discussions}

\subsection{Optimum Moisture Content (OMC) and Maximum Dry Density (MDD)}

The values of OMC and MDD for untreated and RCA treated granular base samples were depicted in Table (6) and Figure (2) illustrated the relation of water content with maximum dry density for untreated granular base material. With appropriate fitting the polynomial curve in Figure (2), the values of maximum dry density and optimum water content $\%$ were as follows:

- $\quad 25 \%$ RCA provided $6.20 \%$ OMC and $2.26(\mathrm{gm} / \mathrm{cm} 3) \mathrm{MDD}$.

- $\quad 50 \%$ RCA provided 6.38\% OMC and $2.25(\mathrm{gm} / \mathrm{cm} 3) \mathrm{MDD}$.

- $\quad 75 \%$ RCA provided 6.80\% OMC and 2.23 (gm/cm3) MDD.

- $\quad 100 \%$ RCA provided $7.10 \% \mathrm{OMC}$ and $2.19(\mathrm{gm} / \mathrm{cm} 3)$ MDD.

Table 6. Result of OMC and MDD

\begin{tabular}{|c|c|c|c|}
\hline \multirow{2}{*}{$\begin{array}{c}\text { Material } \\
\text { type }\end{array}$} & \multirow{2}{*}{$\begin{array}{r}\text { Percent used } \\
(\%)\end{array}$} & \multicolumn{2}{|c|}{ Modified Proctor Compaction Test } \\
\hline & & OMC (\%) & $\operatorname{MDD}(\mathrm{gm} / \mathrm{cm} 3)$ \\
\hline $\begin{array}{l}\text { Untreated } \\
\text { Material }\end{array}$ & -- & 6.18 & 2.28 \\
\hline \multirow[t]{4}{*}{ RCA } & 25 & 6.20 & 2.26 \\
\hline & 50 & 6.38 & 2.25 \\
\hline & 75 & 6.80 & 2.23 \\
\hline & 100 & 7.10 & 2.19 \\
\hline
\end{tabular}




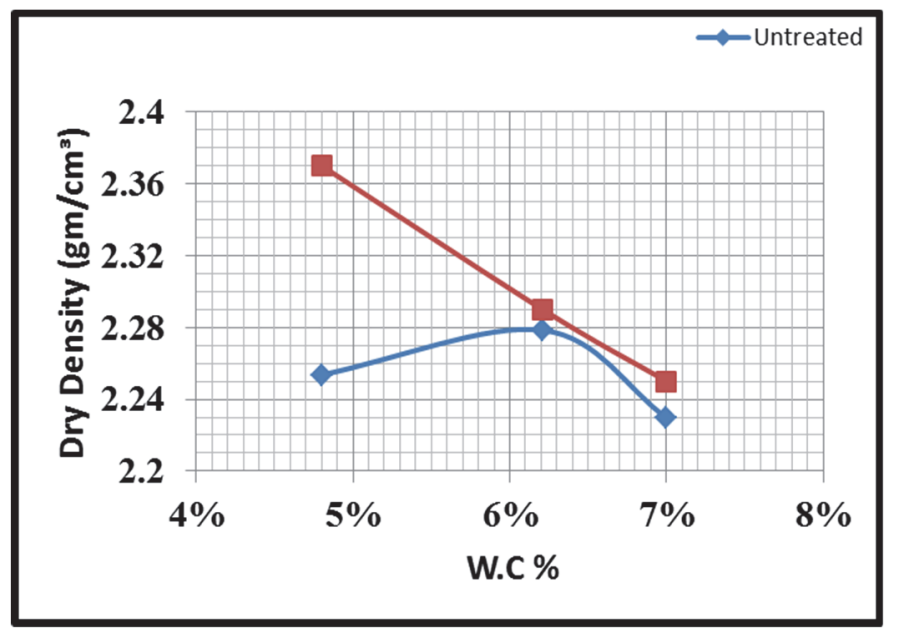

Figure 2. Optimum Moisture Content and Maximum Dry density for Granular Base Layer
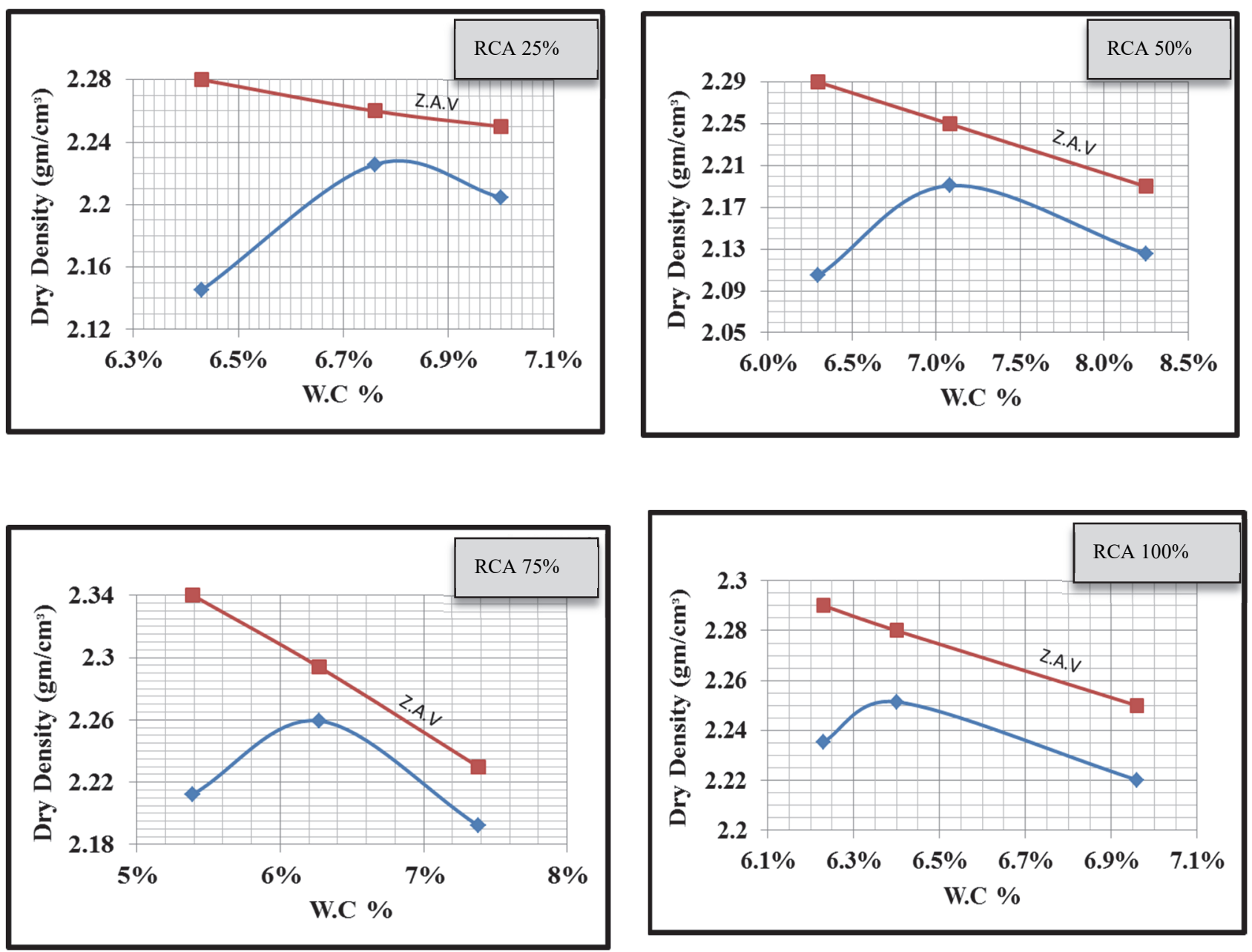

Figure 3. Optimum Moisture Content and Maximum dry density for Granular Base Layer Treated with Different Percentages of RCA

Figure 3 illustrates the effect of (\%) RCA on OMC and MDD for granular base material. The values of OMC decrease and MDD's values increase for granular base material with different percentage of RCA compacted. The OMC's values are increased due to the percentage increment of RCA in granular base material mixture, this 
increment in water content is refer to high percent of fines and the free water get absorbed by the residual cement exist in recycled concrete crushed aggregate. On the other hand the dry density decreased gradually with RCA percentage increment in granular base material mixture, the reason is that the RCA have a lower relative density than that of virgin aggregate as well as the lightweight of adhered cement mortar in RCA can cause a weak layer which decreased the density.

\subsection{Effect of RCA on Elastic Modulus $\left(E_{s}\right)$}

The change in moisture and temperature occurs within road's base layers due to seasonal variation and change in water table level during the pavement design life. The wet-dry conditions may significantly affect performance of pavement. The materials used in road construction should have the ability to provide and enhanced the resistance stability and integrity over years of exposure to the damaging impact of weathering, which is one of most important factors that should be considered in the design life of pavement.

To calculate the modulus of elasticity by using velocity of ultrasonic waves, the equation used in this study illustrated below, test according to ASTM (C 597 - 02) (British Standards Institution, 1988).

$$
\mathrm{E}=\rho \mathrm{v}^{2} \frac{(1+\mathrm{v})(1-2 \mathrm{v})}{(1-\mathrm{v})}
$$

$E$ : Elastic modulus (in $\mathrm{MPa}$ ),

$\rho$ : Density (in $\left.\mathrm{Kg} / \mathrm{m}^{3}\right)$,

v: Pulse velocity (in $\mathrm{Km} / \mathrm{s}$ ), and

V: Poisson's ratio.

Based upon the obtained results for elastic modulus $\left(\mathrm{E}_{\mathrm{s}}\right)$ of granular base material layer, it can be revealed that the $\left(E_{s}\right)$ values is reached $(6927 \mathrm{kPa})$ higher value for $100 \%$ RCA. Table (7) and Figures (4) illustrate the estimated values of $E_{\mathrm{s}}$. The samples subjected to wet -dry cycles are presented in Plate 5 .

Table 7. Elastic Modulus Results for Different Types of Stabilizers Using Modified Proctor Compaction Test and Gyratory Compaction Test.

\begin{tabular}{|c|c|c|}
\hline $\begin{array}{l}(\%) \\
\text { Material Type }\end{array}$ & Elastic Modulus (kPa) & $(\%)$ Increment \\
\hline Virgin Material & 1853 & 0 \\
\hline $25 \% \mathrm{RCA}$ & 1701 & $8.20^{*}$ \\
\hline $50 \% \mathrm{RCA}$ & 5475 & 195.46 \\
\hline $75 \% \mathrm{RCA}$ & 3716 & 100.54 \\
\hline $100 \%$ RCA & 6927 & 273.83 \\
\hline
\end{tabular}

* \% Reduction 


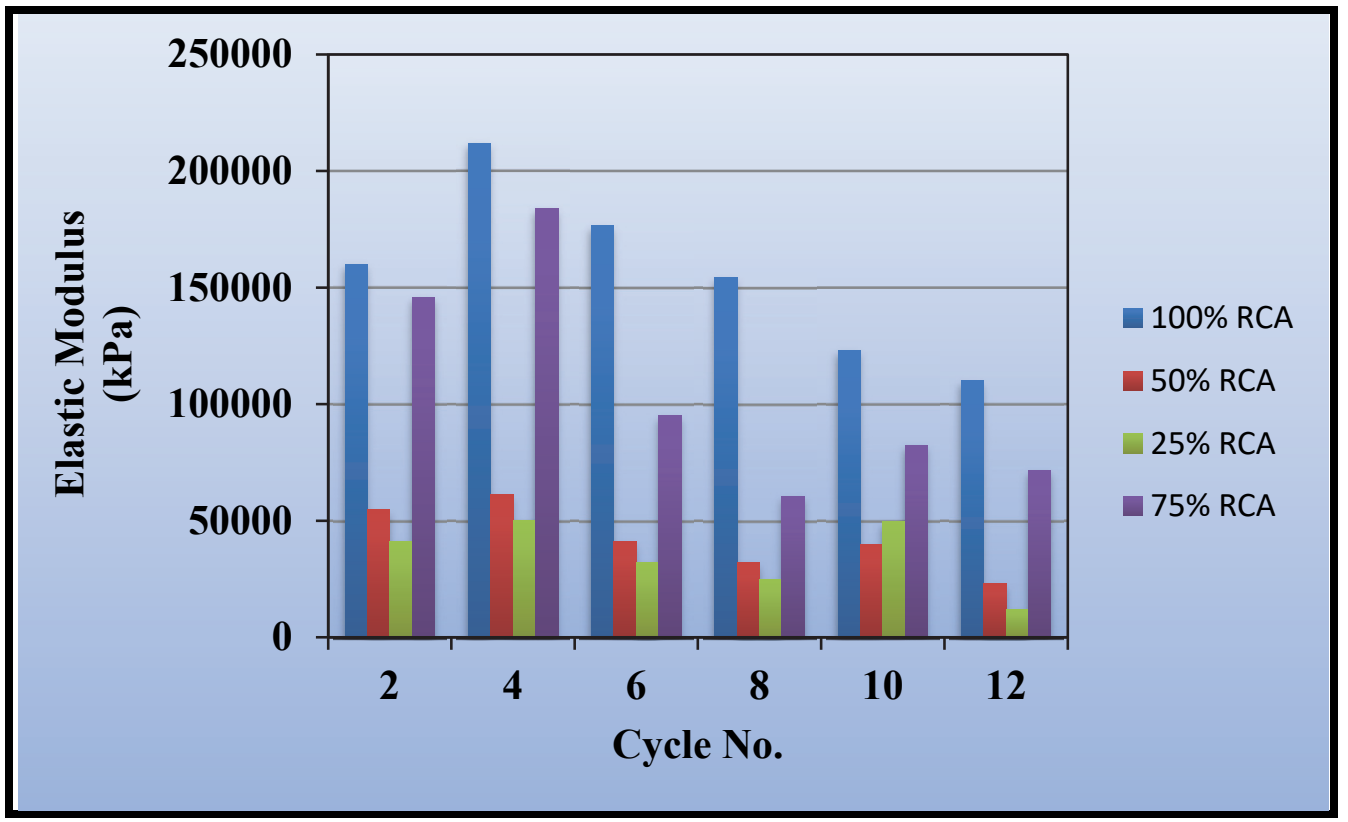

Figure 4. Effect of Wet-Dry Cycle on Elastic Modulus Results for Granular Base Materials Treated with Different \%RCA

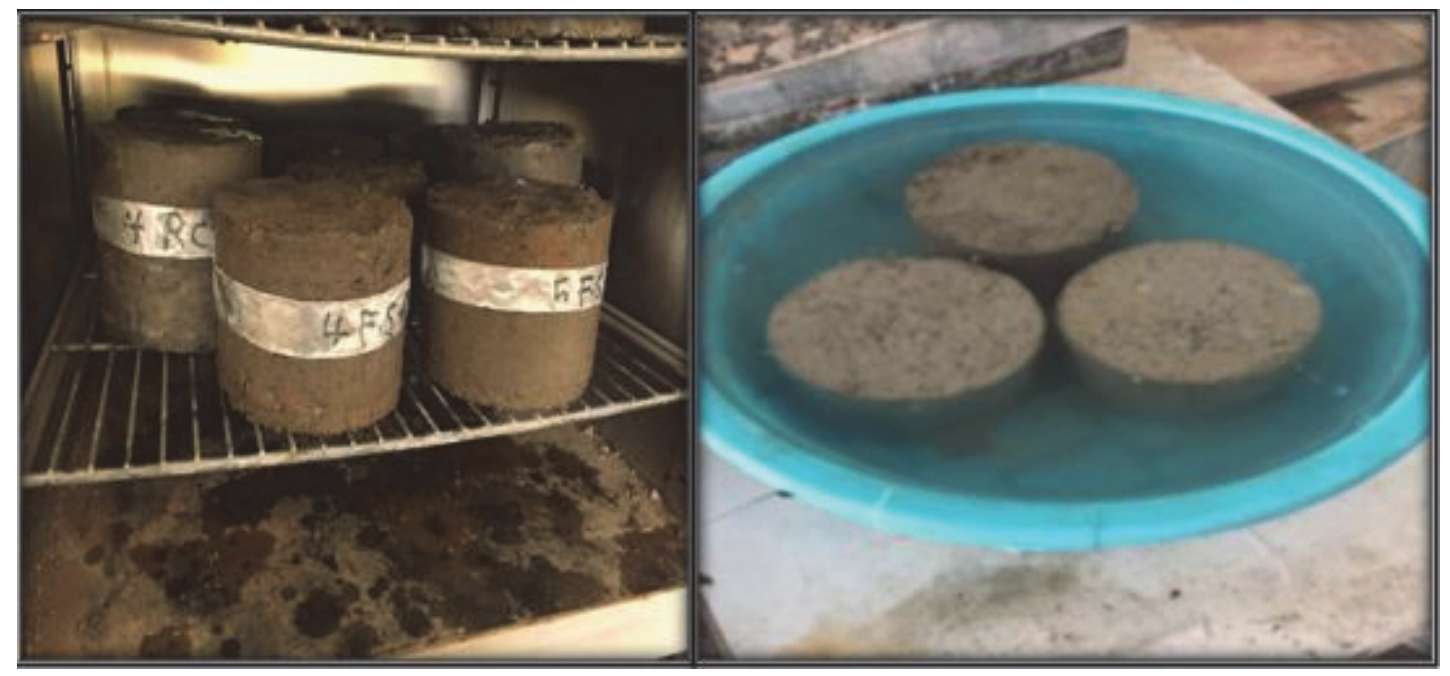

Plate 5. Samples Subjected to Wet-Dry Cycle

\section{Statistical Analysis}

Analyze the results obtained from previous experimental tests; (30) samples for wet dry cycle (durability test) with different RCA \% and ultrasonic test for elastic modulus as described previously, a statistical process is adopted to infer the meaning about the underlying data results and try to describe the true behaviour and provide summaries about the experimental observation that have been made. The central of tendency and variability (spread) are estimated for the dependant variable (elastic modulus) which include the median, mode, mean, standard error of mean, standard deviations, variance, minimum and maximum variables and the Skewness and Kurtosis. Table (5) tested the resulted values of (E) for (30) sample size since the distribution is skewed -right (positive skew of (1.687) which indicated that the mean value of $(5436.1333 \mathrm{kPa})$ was greater than the median of $(3849 \mathrm{kPa})$ and this can be seen clearly in the residual histogram of elastic modulus model; Figure (5). It can be concluded that there is an overestimation for elastic modulus results using the ultrasonic test. 
A multiple linear regression analysis is made for prediction of elastic modulus using the SPSS (software ver.21). Elastic Modulus $(\mathrm{kPa})$ is the dependent variable whereas the independent variable are; No. of wet- dry cycle and Percent (\%) of RCA stabilizer.

To obtain a best fit model at level of confidence (95\%), the independent variables are entered in a stepwise regression method. Table (10) illustrated the details of the Regression Models for Independent Variable Elastic Modulus and Dependant Explanatory Variables; Number of Wet-Dry Cycle, Percent of Stabilizer (RCA). Also the ANOVA test results for predicted model are presented in Table (11). The predicted model summary presented in Table (9) with $\mathrm{R}^{2}$ of 0.682 . The regression coefficients obtained as presented in Table (10) indicated that RCA\% in base material increased the elastic modulus and modulus decreasing with wet-dry cycle.

Table 8. The Descriptive Statistics for Dependant Variable (Elastic Modulus).

\begin{tabular}{lll}
\hline Statistics & & \\
\hline Es & Valid & 30 \\
$\mathrm{~N}$ & Missing & 0 \\
& & \\
Mean & & 5436.1333 \\
Std. Error of Mean & 766.52343 \\
Median & & 3849.0000 \\
Std. Deviation & 4198.42175 \\
Variance & 17626745.223 \\
Skewness & 1.687 \\
Std. Error of Skewness.427 \\
Kurtosis & 2.063 \\
Std. Error of Kurtosis & .833 \\
Range & 16005.00 \\
Minimum & 1701.00 \\
Maximum & 17706.00 \\
& 25 & 3041.0000 \\
Percentiles & 50 & 3849.0000 \\
& 75 & 6072.7500 \\
\hline
\end{tabular}

Table 9. Statistical Model Summary

Model Summary ${ }^{b}$

\begin{tabular}{cccccccccc}
\hline Model & $\mathbf{R}$ & $\begin{array}{c}\mathbf{R} \\
\text { Square }\end{array}$ & $\begin{array}{c}\text { Adjusted } \\
\mathbf{R}\end{array}$ & $\begin{array}{c}\text { Std. Error of } \\
\text { the Estimate }\end{array}$ & \multicolumn{5}{c}{ Change Statistics } \\
\cline { 5 - 9 } 1 & $.682^{\mathrm{a}}$ & .465 & .426 & 3268.43215 & $\begin{array}{c}\text { R Square } \\
\text { Change }\end{array}$ & $\begin{array}{c}\mathbf{F} \\
\text { Change }\end{array}$ & df1 & df2 & $\begin{array}{c}\text { Sig. F } \\
\text { Change }\end{array}$ \\
\hline
\end{tabular}

a. Predictors: (Constant), Stabilizer, Cycle

b. Dependent Variable: Es

Table 10. Details of the Regression Models for Independent Variable Elastic Modulus and Dependant Explanatory Variables; Number of Wet-Dry Cycle, Percent of Stabilizer (RCA)

\begin{tabular}{|c|c|c|c|c|c|c|c|c|c|c|}
\hline \multicolumn{11}{|c|}{ Coefficients } \\
\hline \multirow{2}{*}{\multicolumn{2}{|c|}{ Model }} & \multicolumn{2}{|c|}{$\begin{array}{l}\text { Unstandardized } \\
\text { Coefficients }\end{array}$} & \multirow{2}{*}{ 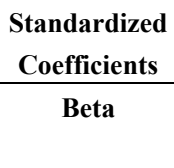 } & \multirow[t]{2}{*}{$\mathbf{t}$} & \multirow[t]{2}{*}{ Sig. } & \multicolumn{2}{|c|}{$\begin{array}{c}\text { 95.0\% Confidence } \\
\text { Interval for B }\end{array}$} & \multicolumn{2}{|c|}{$\begin{array}{l}\text { Co linearity } \\
\text { Statistics }\end{array}$} \\
\hline & & B & $\begin{array}{l}\text { Std. } \\
\text { Error }\end{array}$ & & & & $\begin{array}{l}\text { Lower } \\
\text { Bound }\end{array}$ & $\begin{array}{l}\text { Upper } \\
\text { Bound }\end{array}$ & Tolerance & VIF \\
\hline & (Constant) & 4588.454 & 1262.231 & & 3.635 & .001 & 1998.569 & 7178.339 & & \\
\hline 1 & $\begin{array}{l}\text { No. of Cycle } \\
\text { Percent of (RCA) }\end{array}$ & $\begin{array}{c}-555.480- \\
55.111\end{array}$ & $\begin{array}{c}158.780 \\
18.415\end{array}$ & $\begin{array}{c}-.503- \\
.430\end{array}$ & $\begin{array}{c}-3.498- \\
2.993\end{array}$ & $\begin{array}{l}.002 \\
.006\end{array}$ & $\begin{array}{c}-881.270- \\
17.327\end{array}$ & $\begin{array}{c}-229.689- \\
92.895\end{array}$ & $\begin{array}{l}1.000 \\
1.000\end{array}$ & $\begin{array}{l}1.000 \\
1.000\end{array}$ \\
\hline
\end{tabular}

a. Dependent Variable: Es 
Table 11. ANOVA Test Results for Elastic Modulus Model

\begin{tabular}{llccccc}
\multicolumn{7}{c}{ ANOVA $^{\mathbf{a}}$} \\
\hline Model & & Sum of Squares & df & Mean Square & F & Sig. \\
\hline \multirow{3}{*}{1} & Regression & 251140531.985 & 2 & 125570265.992 & 11.755 & $.000^{\mathrm{b}}$ \\
& Residual & 288431515.882 & 27 & 10682648.736 & & \\
& Total & 539572047.867 & 29 & & & \\
\hline
\end{tabular}

a. Dependent Variable: Es

b. Predictors: (Constant), Stabilizer, Cycle

Also the error distribution mean value for the dependent variable elastic modulus and the P-P plot of regression standardized residual is depicted in Figure (5),(6) and (7).It can be seen that the individual data approximately fit the line which indicated the outcome variables could reveal unexplained patterns in the elastic modulus data by the fitted model. And the bivariate coefficients of correlation which determines the relationship between each of the predictor variable (Elastic Modulus and the dependent variables; percent of stabilizer (RCA) and number of Wet-Dry cycles are shown in Table (12).

Table 12. The Correlation Coefficients between Elastic Modulus and Number of Wet-Dry Cycles; Percent of Stabilizer (RCA).

\begin{tabular}{lcccc}
\multicolumn{5}{c}{ Correlations } \\
\hline \multirow{3}{*}{ Pearson Correlation } & & Es & Cycle & Stabilizer \\
& Es & 1.000 & $-.513-$ & .454 \\
& Cycle & $-.513-$ & 1.000 & $-.008-$ \\
& Stabilizer & .454 & $-.008-$ & 1.000 \\
Sig. (1-tailed) & Es &. & .002 & .006 \\
& Cycle & .002 &. & .483 \\
$\mathbf{N}$ & Stabilizer & .006 & .483 &. \\
& Es & 30 & 30 & 30 \\
& Cycle & 30 & 30 & 30 \\
& Stabilizer & 30 & 30 & 30 \\
\hline
\end{tabular}

From the regression modelling which is a set of statistical process to estimate the relations among selected experimental variables in this research; Number of Wet-Dry Cycles, Percent of stabilizer (RCA), a developed Elastic model is presented as shown below Eq.2 :

$$
E_{s}=4588.454-555.480(\text { No. of Wet }- \text { Dry Cycles })+55.111(\text { Percent of RCA) }
$$

Where:

$\mathrm{E}_{\mathrm{s}}$ : Elastic Modulus (kPa). 


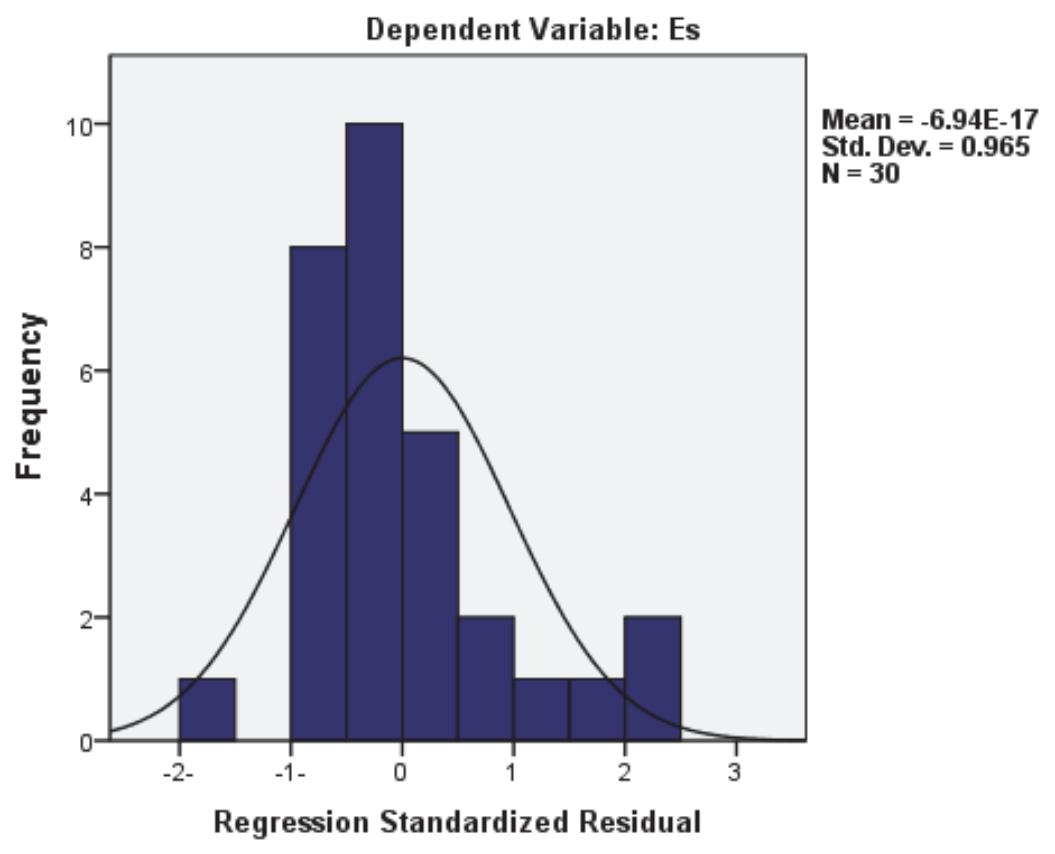

Figure 5. Histogram Residual for Elastic Modulus Model

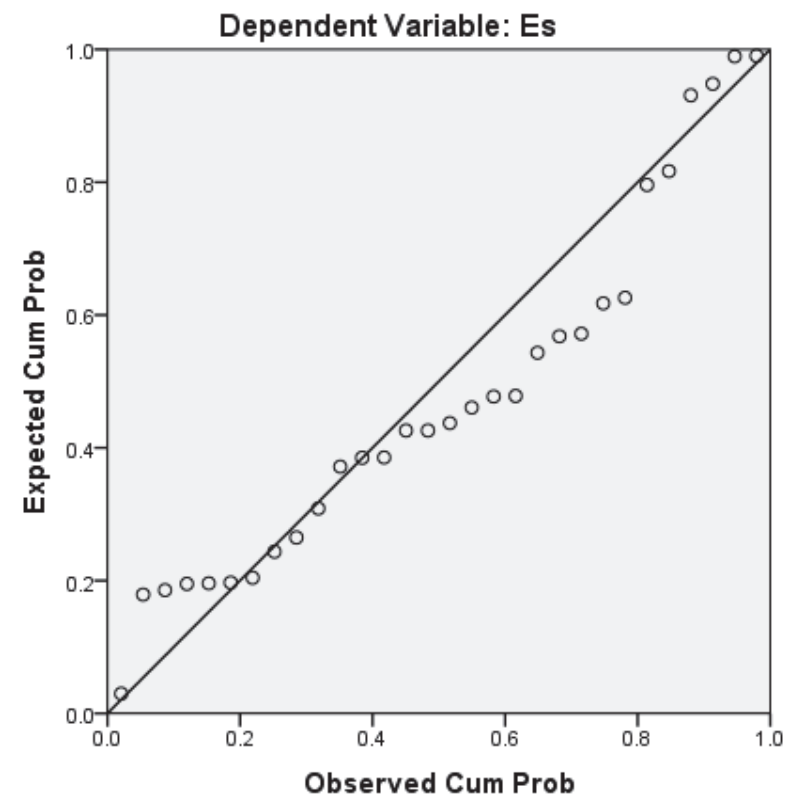

Figure 6. Normal P-P Plot of Regression Standardized Residual 


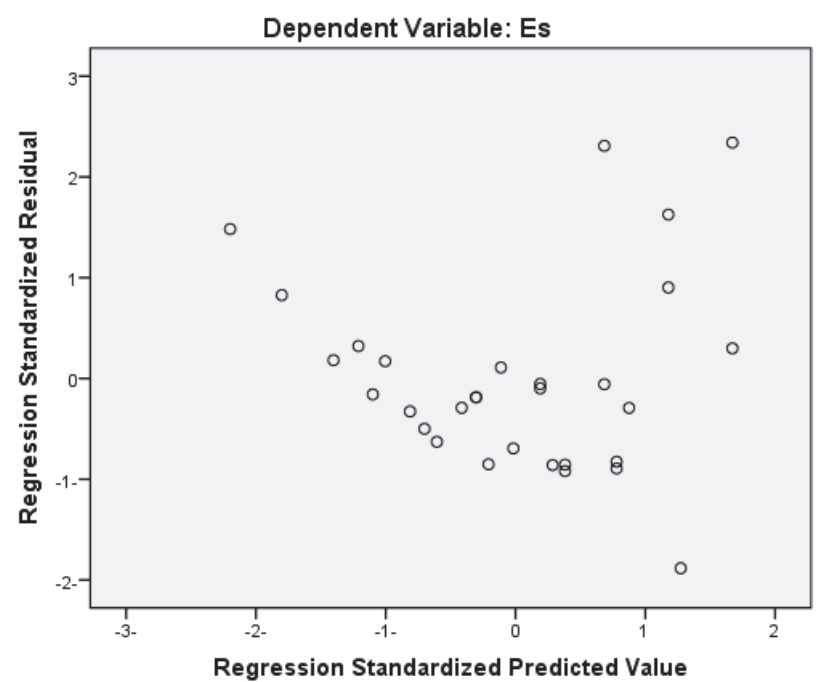

Figure 7. Scatter Plot for Elastic Modulus Model

\subsection{Model Validation}

A best fit is presented in Figure (8) for the predicted elastic modulus model with the obtained experimental results for the model of granular base materials. For building a general model with good performance a $75 \%$ data and $25 \%$ splitting strategy has provided and adopted extra experimental results from previous research (Alkaissi, et. al. 2016). The goodness of fit for predicted model and experimental estimated data for elastic modulus have been checked using chi-square test as shown below so the developed model is considered to be valid.

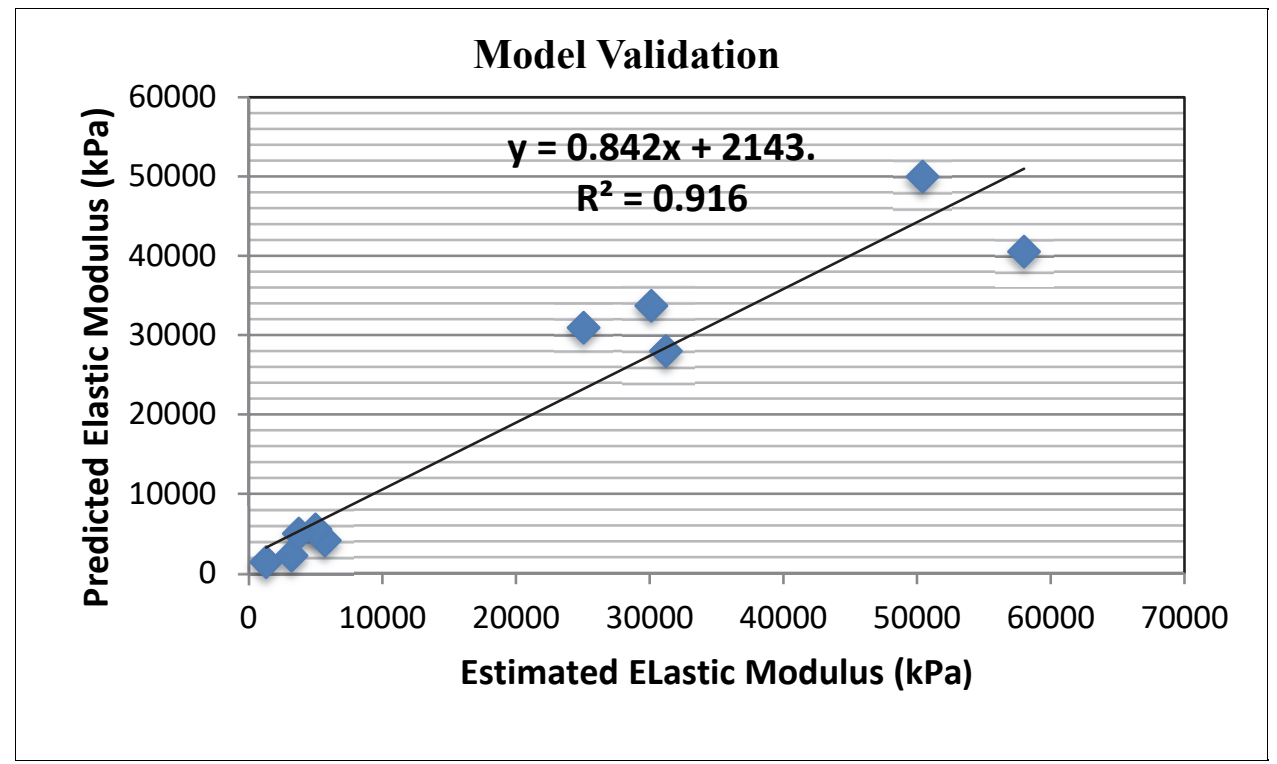

Figure 8. Predicted Elastic Modulus Model Versus Estimated Elastic Modulus for Granular Base Materials

\section{Conclusions}

From the acquired of this research, the following conclusions can be accomplished:

1. The values of maximum dry density and optimum water content $\%$ were as follows:

- $25 \%$ RCA provided $6.20 \%$ OMC and $2.26(\mathrm{gm} / \mathrm{cm} 3)$ MDD.

- $\quad 50 \%$ RCA provided $6.38 \%$ OMC and $2.25(\mathrm{gm} / \mathrm{cm} 3)$ MDD. 
- $\quad 75 \%$ RCA provided 6.80\% OMC and $2.23(\mathrm{gm} / \mathrm{cm} 3) \mathrm{MDD}$.

- $100 \%$ RCA provided 7.10\% OMC and $2.19(\mathrm{gm} / \mathrm{cm} 3)$ MDD.

2. The obtained results for elastic modulus (Es) of granular base material layer showed an increasing in elastic modulus with percentage of RCA\%., it can be revealed that the (Es) values is reached maximum value $(6927 \mathrm{kPa})$ for $100 \%$ RCA.

3. A multiple linear regression analysis is made for prediction of elastic modulus using the SPSS (software ver.21). Elastic Modulus $(\mathrm{kPa})$ is the dependent variable whereas the independent variable are; No. of wet- dry cycle and Percent (\%) of RCA stabilizer.

A prediction Elastic model is presented as shown below:

$$
\mathrm{E}_{\mathrm{s}}=4588.454-555.480 \text { (No. of Wet }- \text { Dry Cycles) }+55.111 \text { (Percent of RCA) }
$$

\section{References}

Alkaissi, Z. A., Jabbar, A., \& Abdulhassan E. (2016). Evaluation the Performance of Treated Base Layer on Critical Response of Flexible Pavement. Journal of Engineering and Sustainable Development, 20(5).

American Society for Testing and Materials. (2007). Standard Test Methods for Laboratory Determination of Water (Moisture), ASTM D2216 - 05.

American Society for Testing and Materials, (Standard Test Methods for Wetting and Drying Compacted SoilCement Mixtures), ASTM D559 / D559M - 15.

American Society for Testing and Materials (Standard Test Method for Pulse Velocity Through Concrete), ASTM C597 - 02.

ASTM C597-02 (2008). Standard Test Methods for Pulse Velocity Through Concrete ASTM International, West Conshohocken, PA.

ASTM D698 - 12 (2009). Standard Test Methods for Laboratory Compaction Characteristics of Soil Using Standard Effort ASTM International, West Conshohocken, PA.

ASTM Standard D2487 (2000). Standard Practice for Classification of Soils for Engineering Purposes (Unified Soil Classification System). ASTM International, West Conshohocken, PA, 2000. https://doi.org/10.1520/D2487-00, www.astm.org

Biswal, et. al. (2018). Strength and Stiffness Studies of Cement Stabilized Granular Lateritic Soil" International Congress and Exhibition. Sustainable Civil Infrastructures, Soil Testing, Soil Stability and Ground Improvement, 320-336.

Iraqi General Specification for Roads and Bridges. (2003). Standard Specification for Roads and Bridges. The state Corporation for Road and Bridges, Revised Edition.

SPSS (Statistical Package for the Social Sciences) IBM SPSS Statistics software ver.21.

Titi, H. H., \& Matar, M. (2018). Estimating Resilient Modulus of Base Aggregates for Mechanistic-Empirical Pavement Design and Performance Evaluation. Transportation Geotechnics, 17(2018), 141-153, Elsevier. https://doi.org/10.1016/j.trgeo.2018.09.014

Titi, H. H., Dakwar, M., Sooman, M., \& Tabatabai, H. (2018). Long Term Performance of Gravel Base Course Layers in Asphalt Pavements. Journal of Case Studies in Construction Materials. Elsevier. https://doi.org/10.1016/j.cscm.2018.e00208

\section{Copyrights}

Copyright for this article is retained by the author(s), with first publication rights granted to the journal.

This is an open-access article distributed under the terms and conditions of the Creative Commons Attribution license (http://creativecommons.org/licenses/by/4.0/). 